\title{
Simulating Strength Behaviors of Corner Joints of Wood Constructions by Using Finite Element Method
}

\section{Simuliranje naprezanja u kutnim spojevima drvenih konstrukcija primjenom metode konačnih elemenata}

\author{
Original scientific paper • Izvorni znanstveni rad \\ Received-prispjelo: 15. 1. 2015. \\ Accepted-prihvaćeno: 5. 5. 2016. \\ UDK: $630 * 812.472 ; 630 * 824.132$ \\ doi:10.5552/drind.2016.1503
}

\begin{abstract}
Using finite element method (FEM) has become wide spread in the field of wood mechanics for analyzing difficult problems instead of conventional methods. The objective of this study is to determine the strength properties of wood corner joints using FEM. For this purpose, diagonal compression and diagonal tension experiments were carried out using dowel, mortise and tenon elements. Corner joints (L-type) were prepared with Scotch pine (Pinus sylvestris L.) and Beech (Fagus orientalis Lipsky) woods. Data obtained experimentally were used in FEM computer modeling to determine structural specifications of wood materials. The amount of deformation as a result of compression-tension in the corner joints was determined and then simulated with a computer program using FEM (ANSYS Multiphysics/LS-DYNA). As a result, the amount of deformation obtained from experiments was consistent with the FEM computer modeling with 90 to $97 \%$. It is suggested that strength properties of joints can be forecast by using FEM computer modeling instead of physical experiments that may cause loss of time, increase of cost and destruction of materials.
\end{abstract}

Key words: Finite Element Method (FEM), ANSYS/LS-DYNA, wood, strain gauge, wooden corner joints, dowel, mortise, tenon

SAŽETAK • Za analizu složenih problema u području mehanike drva umjesto konvencionalnih metoda vrlo se često primjenjuje metoda konačnih elemenata (FEM). Cilj istraživanja ovog rada bio je odrediti naprezanja drvenih kutnih spojeva uz pomoć metode konačnih elemenata. Za tu su namjenu provedeni eksperimenti dijagonalnoga tlačnog naprezanja i dijagonalnoga vlačnog naprezanja drvenih spojeva s moždanicima, uz primjenu čepa i rupe. Kutni spojevi (L-tip) pripremljeni su od drva škotskog bora (Pinus sylvestris L.) i bukve (Fagus orientalis Lipsky). Eksperimentalno dobiveni podatci upotrijebljeni su za FEM računalno modeliranje kako bi se utvrdila strukturna obilježja drvnih materijala. Određena je veličina deformacije kutnih spojeva kao posljedica tlačnog naprezanja, a zatim je simulirana primjenom računalnog programa i metode konačnih elemenata (ANSYS Multiphysics/LS-Dyna). Rezultati su pokazali da veličina deformacije dobivena modeliranjem i primjenom metode konačnih elemenata odgovara veličini deformacije dobivene eksperimentalnim mjerenjem, i to u iznosu 90 - $97 \%$.

\footnotetext{
Authors are assistant professors at Bartin University, Forestry Faculty, Department of Forest Industry Engineering, Bartin, Turkey.

Autori su docenti Sveučilišta u Bartinu, Šumarski fakultet, Odjel za drvnu tehnologiju, Bartin, Turska.
} 
Istraživanjem je također utvrđeno da se čvrstoća kutnih spojeva može dobro predvidjeti FEM računalnim modeliranjem umjesto provedbom eksperimenata koji zahtijevaju više vremena, povećane troškove $i$ uništavanje većih količina materijala.

Ključne riječi: metoda konačnih elemenata (FEM), ANSYS/LS-DYNA, drvo, mjerenje naprezanja, drveni kutni spojevi, spoj moždanicima, spoj čep - rupa

\section{INTRODUCTION}

\section{UVOD}

Frame structure represents the most widely used type of furniture constructions. The strength of corner joints in the construction of case-type furniture has a direct effect on the durability of the product. There are a lot of researches related to corner joints in case construction of furniture and frame constructions (Dalvand et al., 2014; Nicholls and Crisan, 2002; Cai et al., 1995; Eckelman and Suddarth, 1969). Some researches of the strength of furniture joints have mainly focused on mortise and tenon joints and dowel joints (Atar et al., 2009).

The rapid development of technology makes the solution to problems encountered in daily life much harder and more complicated. The computer has become an analysis tool that facilitates solutions to these hardships and problems. Therefore, it is possible to produce approximate numeric solutions through simulations. The finite element method (FEM) is a numeric analysis method in which the problem is simulated while considering the physical conditions and features of the materials. Using FEM computer modeling can enable faster, less costly, more optimized product development and examination of detailed product performance that would not be possible to observe experimentally (Yorur, 2012).

Finite Element Method (FEM), applied in various disciplines, is a numerical method used to solve engineering problems that require special analysis. Joints were discussed in the literature, by using different analyzing programs and model approaches of case type furniture (Gustafsson, 1995; Gustafsson, 1996; Gustafsson, 1997; Smardzewski, 1998; Smardzewski, 2002; Nicholls and Crisan, 2002; Guindos and Guaita, 2013; Tankut et al, 2014). The literature about finite element method is rich, but there is not sufficient information about wood and wooden materials using FEM computer modeling. The purpose of this research is to answer the question "Can we use a computer aided model instead of physical experiments?"

\section{MATERIALS AND METHODS}

\section{MATERIJALI I METODE}

\subsection{Materials}

2.1. Materijali

Beech (Fagus orientalis Lipsky) and Scotch pine (Pinus sylvestris Lipsky) wood samples were selected randomly from timber merchants of Bartin in Turkey. For selection of the wood samples, some specifications (non-deficient, proper, knotless, normally grown without zone line, without reaction wood and without de- cay, insect mushroom damages) were considered according to TS 2470 (TS 2470, 1976).

PVAc D3 adhesive was provided from Polisan, a producer company in Izmit, Turkey. PVAc D3 is an odorless and non-flammable adhesive manufactured according to BS EN204 (BS EN204, 2001) (D3) and DIN 68602 (DIN 68602, 1979) standards. The density of the PVAc D3 adhesive is $1.1 \mathrm{~g} / \mathrm{m}^{3}$. Based on TS 3891 (TS 3891, 1983), approximately $200 \mathrm{~g} / \mathrm{m}^{2}$ of the adhesive were applied to all surfaces of the mortisetenon and dowel joints.

Dowels produced from beech wood $(10 \mathrm{~mm}$ in diameter x $57 \mathrm{~mm}$ long) were used in samples following the standard TS 4539 (TS 4539, 1985). To ensure the strength of the holes in the wood, a 35-mm-deep hole with a diameter of $10 \mathrm{~mm}$ was drilled in element " $A$ " using Computer Numerical Control drill machine, while a 25-mm-deep hole was drilled in element "B". FEM analyses were also carried out by using the same values. Mortise dimensions (width $\mathrm{x}$ length $\mathrm{x}$ depth $14 \mathrm{x} 28 \mathrm{x}$ $32,15 \mathrm{~mm}$ ) were chosen in samples according to the standard TS 4905 (TS 4905, 1986). Holes of "tenon and mortise joints" were first drilled in element B to form the mortise and then element A was prepared for the tenon. Finally, A and B elements were fit to each other. Glue line was $0.15 \mathrm{~mm}$ in thickness for the joint section of all construction parts (dowel and mortise - tenon)

The strain gauges used in the experiments were provided from the manufacturer HBM and had a standard range of $120 \Omega \pm 0.35 \%$. The strain gauge version was 20/120LY41. The size of the strain gauges was 32 $\mathrm{x} 3.2 \mathrm{~mm}$. During the experiment, the deformation values gathered from testbox-1001 were saved and tension values were obtained.

\subsection{Preparation of samples}

2.2. Priprema uzoraka

As experimental schedule showed in Table 1, a total of 80 experimental samples were used for these studies; two species of wood (Beech and Scotch pine), two joint types (dowel and mortise-tenon), two test methods (diagonal compression and tension), and ten repetitions. A total of 80 samples were conditioned in a room with the temperature of $20^{\circ} \mathrm{C}$ and a relative humidity of $65 \%$ until they reached $12 \%$ equilibrium moisture content. Each L-type corner joint test sample consisted of two elements: "A" with dimensions of $158 \times 42 \times 42 \mathrm{~mm}$ and "B" with dimensions 200x42x42 of mm.

During the experiment, a strain gauge was bonded $10 \mathrm{~mm}$ far from the joint section of the elements for each sample (the inner edge) and the deformation values were measured by 20/120LY41 strain gauges. The same conditions as in the experiments were applied for computer modeling. 
Table 1 Experimental design

Tablica 1. Parametri eksperimenta

\begin{tabular}{|c|c|c|c|}
\hline $\begin{array}{l}\text { Wood species } \\
\text { Vrsta drva }\end{array}$ & $\begin{array}{l}\text { Joint types } \\
\text { Vrsta spoja }\end{array}$ & $\begin{array}{c}\text { Tests } \\
\text { Ispitni postupak }\end{array}$ & $\begin{array}{c}\text { Number of } \\
\text { samples } \\
\text { Broj uzoraka }\end{array}$ \\
\hline \multirow{2}{*}{$\begin{array}{l}\text { Beech } \\
\text { bukovina }\end{array}$} & Dowel / spoj moždanicima & \multirow{2}{*}{$\begin{array}{l}\text { Diagonal compression / dijagonalno tlačno naprezanje } \\
\text { Diagonal tension / dijagonalno vlačno naprezanje }\end{array}$} & \multirow{2}{*}{40} \\
\hline & Mortise-tenon / spoj čep - rupa & & \\
\hline \multirow{2}{*}{$\begin{array}{l}\text { Scotch pine } \\
\text { škotska borovina }\end{array}$} & Dowel / spoj moždanicima & \multirow{2}{*}{$\begin{array}{l}\text { Diagonal compression / dijagonalno tlačno naprezanje } \\
\text { Diagonal tension / dijagonalno vlačno naprezanje }\end{array}$} & \multirow{2}{*}{40} \\
\hline & Mortise-tenon / spoj čep - rupa & & \\
\hline
\end{tabular}

\subsection{Method}

\subsection{Metoda}

Load application in diagonal compression for FEM computer modeling is shown in Figure 1a. and in diagonal tension in Figure 1b. Loading continued until the strength values at the joint section decreased.

To determine the strength of the L-type dowel and mortise-tenon corner joints, diagonal compression and tension tests were applied with a zwick roell Z50 universal test machine. The loading speed of the machine throughout the tests was adjusted to $5 \mathrm{~mm} / \mathrm{min}$ ute. The loading continued until there was a break or separation at the joint sections of the samples and, at this instant, the load $\left(F_{\max }\right)$ was determined and recorded. The same amount of the load that caused the experiment break was considered for computer modeling. In computer modeling (ANSYS/LS-DYNA), material selection was made after the method was determined. The chosen element was solid 164. Solid 164 is an 8-pointed solid element that contains features of cracking in tension, crushing in compression, plastic deformation and elasticity. It has 3 directional motions independent in $x, y$ and $z$ directions in the nodes. Punches and anti-friction lining were shell 163. Plastic kinematic was chosen as material properties in ANSYS. The material properties listed in Table 2 were obtained experimentally.

These properties of experiment samples were also chosen for FEM computer modeling. As shown in Figure 2, the L-type corner joint was placed under punch contact point. As in the experiments, B element
Table 2 Material properties used in ANSYS/LS-DYNA Program

Tablica 2. Svojstva materijala uvrštena u računalni program ANSYS/LS-DYNA

\begin{tabular}{|c|c|c|c|}
\hline \multicolumn{2}{|c|}{$\begin{array}{l}\text { Mechanical features } \\
\text { Mehanička svojstva }\end{array}$} & \begin{tabular}{|l|} 
Yellow Pine \\
Borovina
\end{tabular} & $\begin{array}{c}\text { Beech } \\
\text { Bukovina }\end{array}$ \\
\hline \multicolumn{2}{|c|}{ Density / gustoća, $\mathrm{g} / \mathrm{cm}^{3}$} & 0.52 & 0.67 \\
\hline \multicolumn{2}{|c|}{$\begin{array}{l}\text { Elasticity module / modul } \\
\text { elastičnosti, N/mm } 2\end{array}$} & 10.500 & 12.500 \\
\hline \multicolumn{2}{|c|}{$\begin{array}{l}\text { Poisson rate / Poissonov } \\
\text { koeficijent, } v\end{array}$} & 0.30 & 0.35 \\
\hline \multicolumn{2}{|c|}{ Leakage / puzanje materijala } & 32.0 & 50.0 \\
\hline \multicolumn{2}{|c|}{ Stretching / istezanje } & 0.03 & 0.03 \\
\hline \multirow{2}{*}{$\begin{array}{l}\text { Contact friction } \\
\text { Koeficijent } \\
\text { trenja }\end{array}$} & Static/statički & 0.30 & 0.30 \\
\hline & $\begin{array}{l}\text { Dynamic } \\
\text { dinamički }\end{array}$ & 0.70 & 0.70 \\
\hline
\end{tabular}

was placed on the nick in the metal plate. For diagonal compression, the metal plate was fixed in directions of $x, y, z$ in FEM computer modeling but for diagonal tension it was fixed in directions of $y$ and $z$ and released in the direction of $x$. The punch was fixed only in $x$ and $z$ directions, and in the $y$ direction, only downward movement was allowed, without rotational movement. For a dowel, the number of elements was 45295 and the number of nodes was 9538. For tenon joints, these numbers were 44725 and 9450 , respectively. As a result of the punch movements, the internal force distribution and directions of samples in FEM computer modeling are shown in Figure 2. (a)

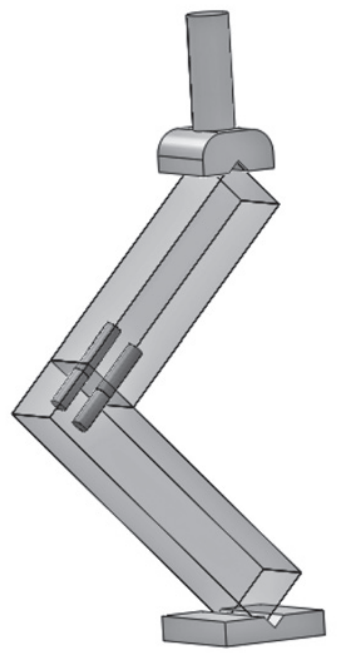

(b)

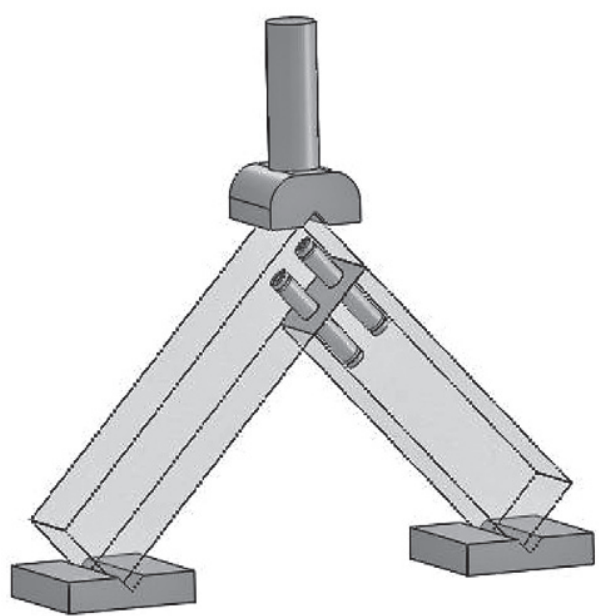

Figure 1 Models for diagonal compression tests (a) and diagonal tensile tests (b).

Slika 1. Modeli za ispitivanje dijagonalne tlačne čvrstoće (a) i dijagonalne vlačne čvrstoće (b) 

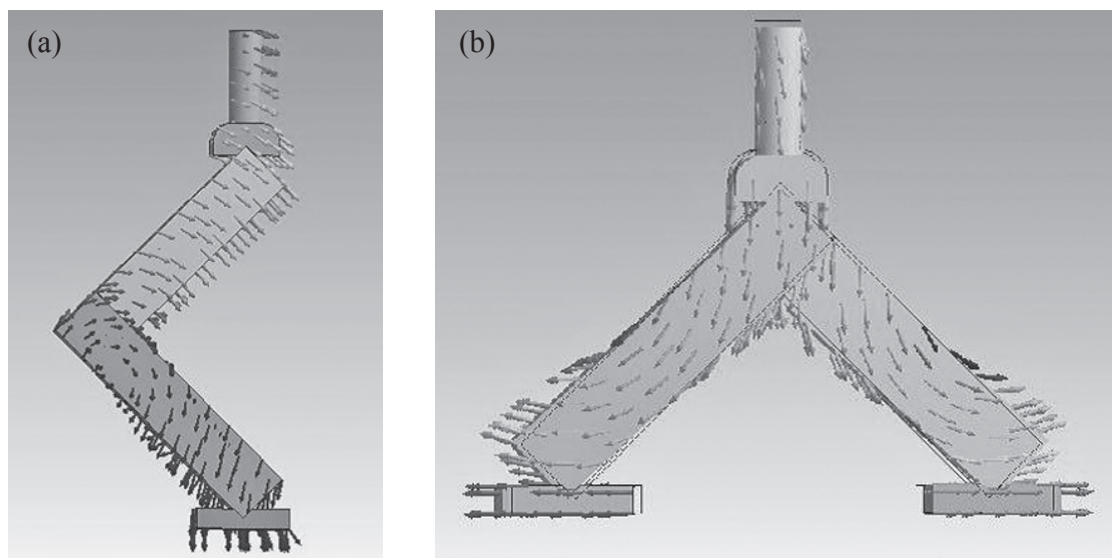

Figure 2 Distribution and direction of force in diagonal compression (a) and diagonal tension (b) samples Slika 2. Raspodjela i smjer sila pri dijagonalnom tlačnom naprezanju (a) i dijagonalnom vlačnom naprezanju (b)

\section{RESULTS AND DISCUSSION}

\section{REZULTATI I RASPRAVA}

The results of diagonal compression and diagonal tension strength tests of L-type corner joints were compared with the strength, strain gauge analysis and stress analysis parameters and the compliance between them is shown in Figure 3, 4 and 5.

As seen in Figure 3, experimental and Ansys results comply with each other. The highest compliance between experimental strength and FEM analysis strength values was obtained in beech dowel joint with $97.76 \%$ and the lowest compliance was obtained in beech tenon with $86.2 \%$. Imirzi (2008) compared experimental and Ansys results and obtained the compliance of about $60-81 \%$.

As seen in Figure 4, experimental and Ansys results comply with each other. The highest compliance between experimental strain gauge analysis and FEM computer modeling values was obtained in beech mortise-tenon joint with $96.35 \%$ and the lowest compliance was obtained in Scotch pine dowel with $71.4 \%$.
In her study, Ertas (2007) used strain gauge technology and stress analysis methods to design industrial products. She suggested that these methods may be useful to recognize certain forms and materials in industrial design.

According to Figure 5, the highest compliance between experimental stress analysis and FEM computer stress analysis values was obtained in beech mortise-tenon joint with the compliance of $93.82 \%$ and the lowest compliance was obtained in Scotch pine dowel with $72.09 \%$.

The differences between the experimental and FEM analysis results can be explained by sensitivity of the nodes that were chosen to place strain gauge and also by anisotropic characteristics of wooden materials.

\subsection{Performance of diagonal compression} strength for FEM analysis

3.1 Svojstvo dijagonalne tlačne čvrstoće za FEM analizu

The initial deformation was observed in the upper dowel due to continuous tension and momentum effect and then the tension in the lower dowel reached

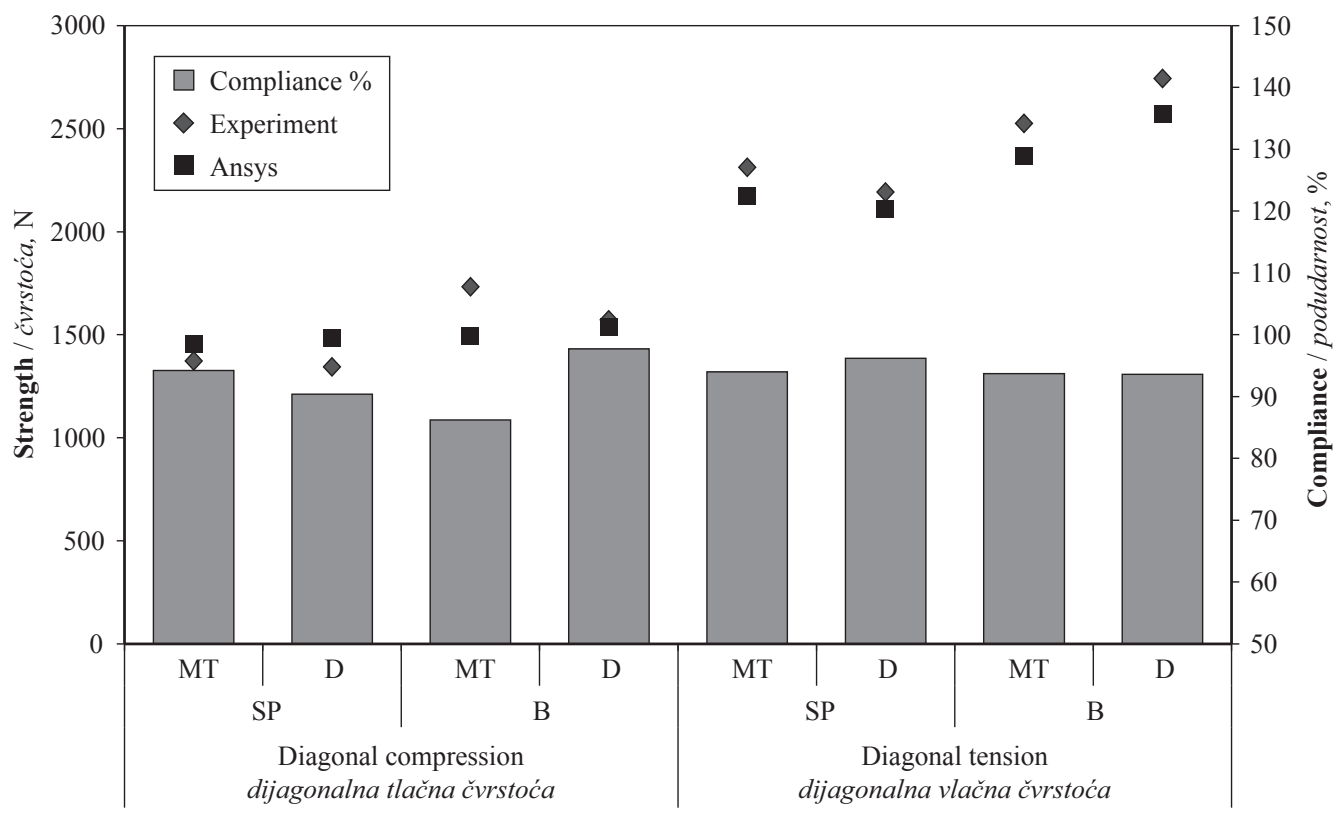

Figure 3 The results of diagonal compression and diagonal tension strength tests of L-type corner joints Slika 3. Rezultati ispitivanja dijagonalne tlačne čvrstoće i dijagonalne vlačne čvrstoće kutnih spojeva L-tipa 


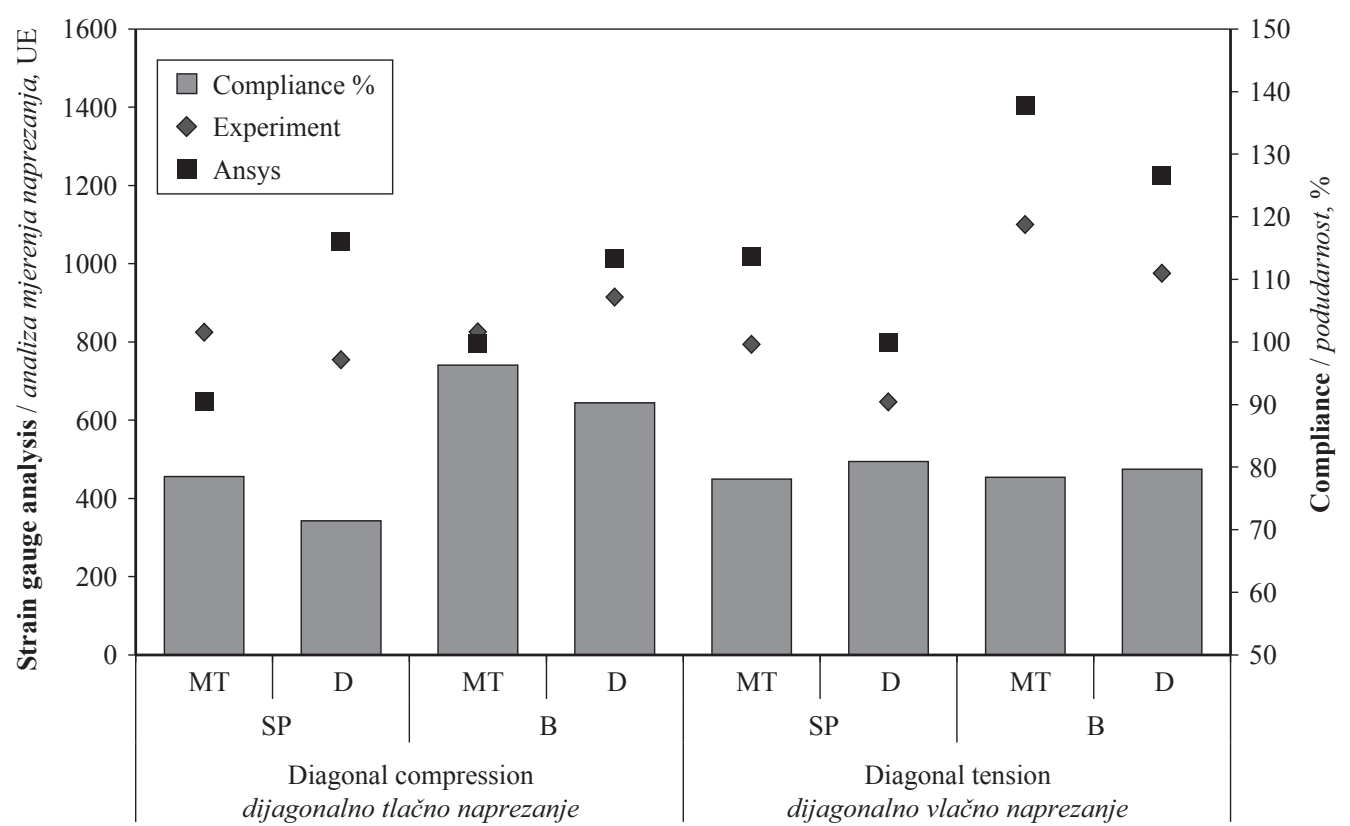

Figure 4 The results of strain gauge analysis of L-type corner joints Slika 4. Rezultati analize mjerenja naprezanja kutnih spojeva L-tipa

the highest value after the upper dowel break as shown in Figure 6.

When the punch moved $4.604 \mathrm{~mm}$ down, 30.807 MPa maximum surface stress, 55.598 Mpa upper dowel stress and also 51.075 MPa lower dowel stress were obtained in L-type corner joints as shown in Figure 6.

In the diagonal compression tests of the L-type mortise-tenon corner joints, initial break occurred in the upper section of the tenon joint. Deformation started and then break was also seen in the edge of element B mortise. The results of FEM computer modeling shown in Figure 7 comply with the results of the experiments.

When the punch moved $9.409 \mathrm{~mm}$ down, 7.934 MPa maximum surface stress, 32.456 Mpa maximum tenon diagonal compression strength stress was obtained in L-type corner joints as shown in Figure 7.

\subsection{Performance of diagonal tension strength for} FEM analysis

3.2 Svojstvo dijagonalne vlačne čvrstoće za FEM analizu

Similar strength values between experiment and FEM analysis were obtained. In the computer model, deformation and tension initially started in lower parts and then breaking occurred.

Figure 8 shows the stress and deformations in the dowel joint beech samples for the diagonal tension tests.

When the punch moved $5.812 \mathrm{~mm}$ down, 15.229 MPa maximum surface stress, 52.095 Mpa maximum dowel diagonal tension strength stress was obtained in L-type corner joints as shown in Figure 8.

Figure 9 shows stress and deformations in the mortise-tenon joint of Scotch pine samples for diagonal tension tests

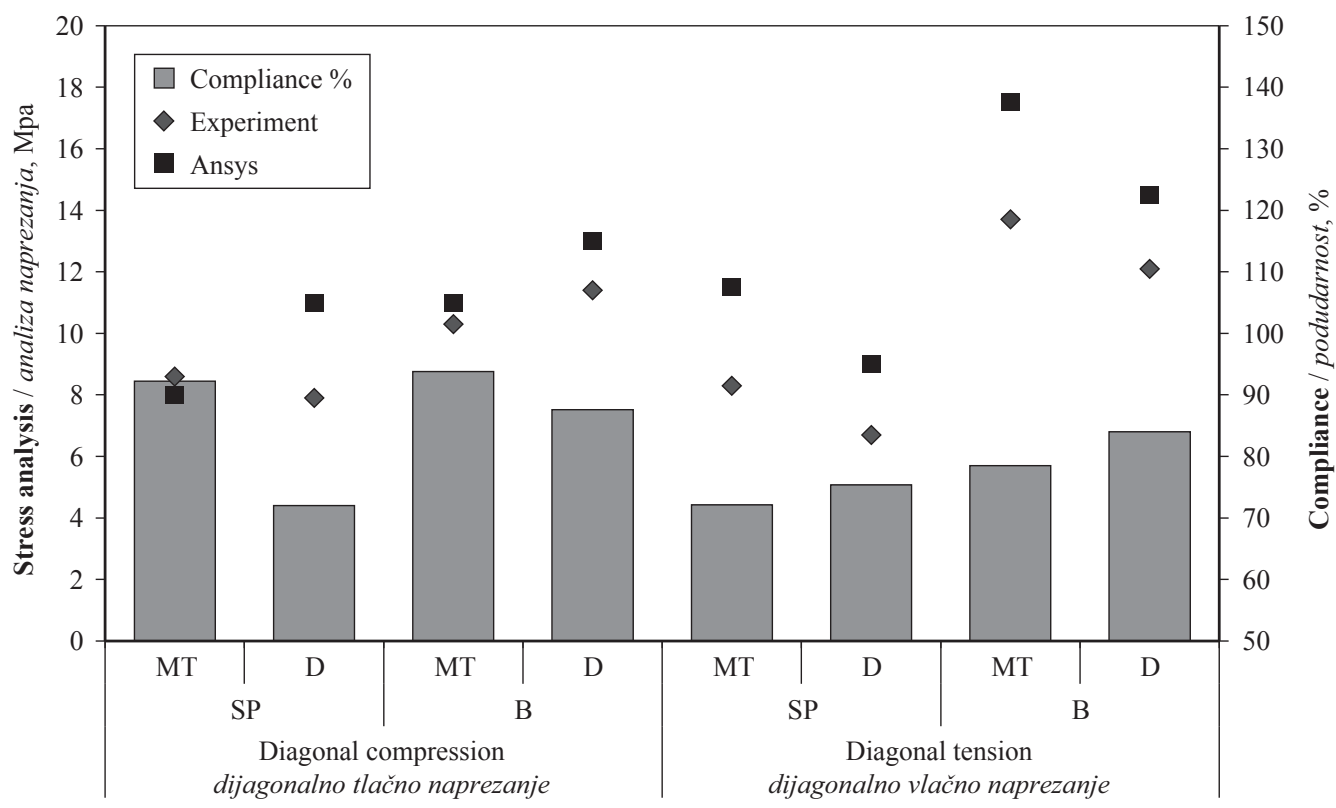

Figure 5 The results of diagonal compression and diagonal tension strength stress analysis of L-type corner joints Slika 5. Rezultati analize dijagonalne tlačne čvrstoće i dijagonalne vlačne čvrstoće kutnih spojeva L-tipa 

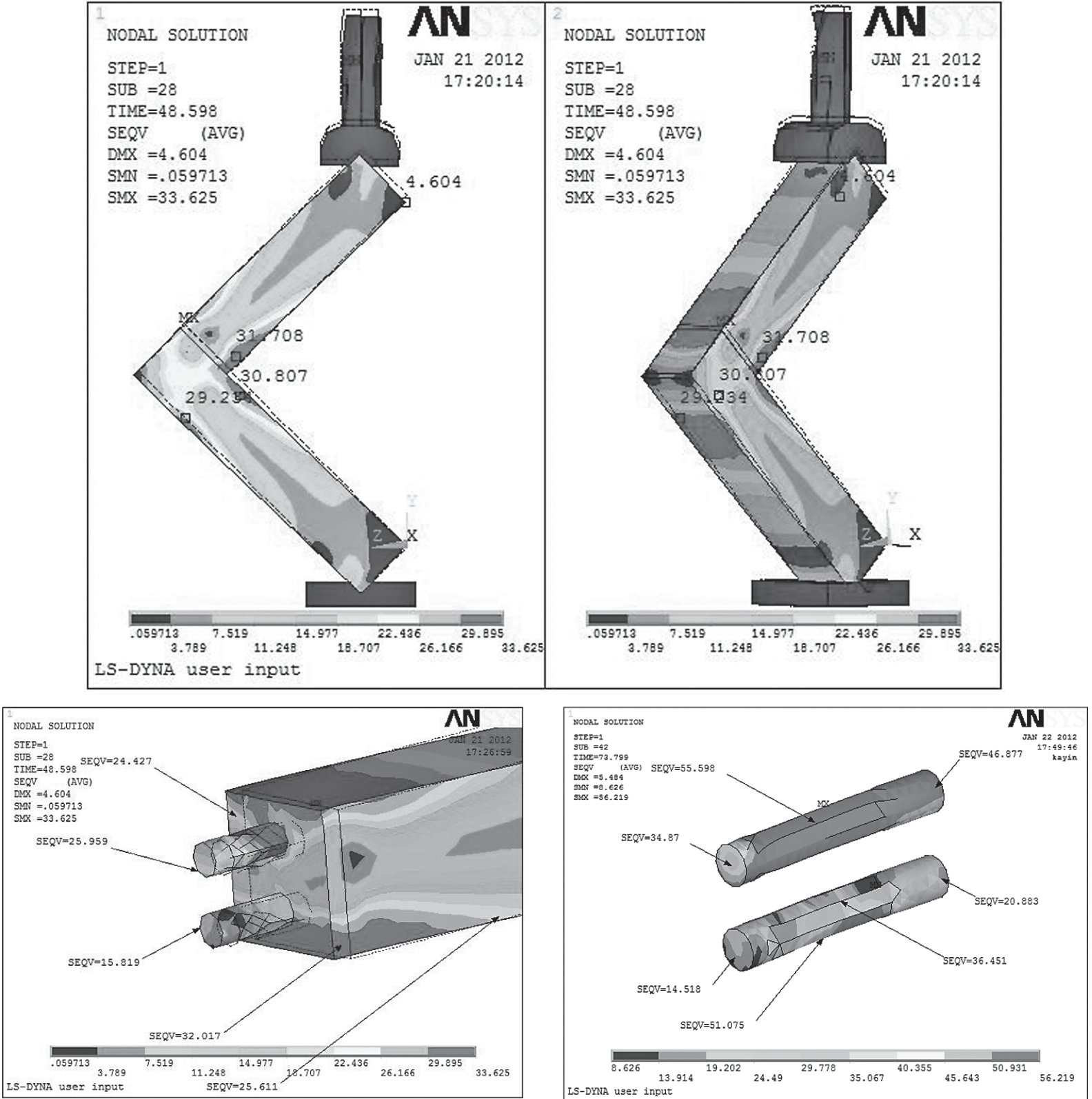

Figure 6 Diagonal compression strength stress and deformations in dowel joint samples of Scotch pine for the diagonal compression tests

Slika 6. Dijagonalna tlačna naprezanja i deformacije uzoraka spojeva s moždanicima izrađenih od drva bora pri ispitivanju dijagonalne tlačne čvrstoće
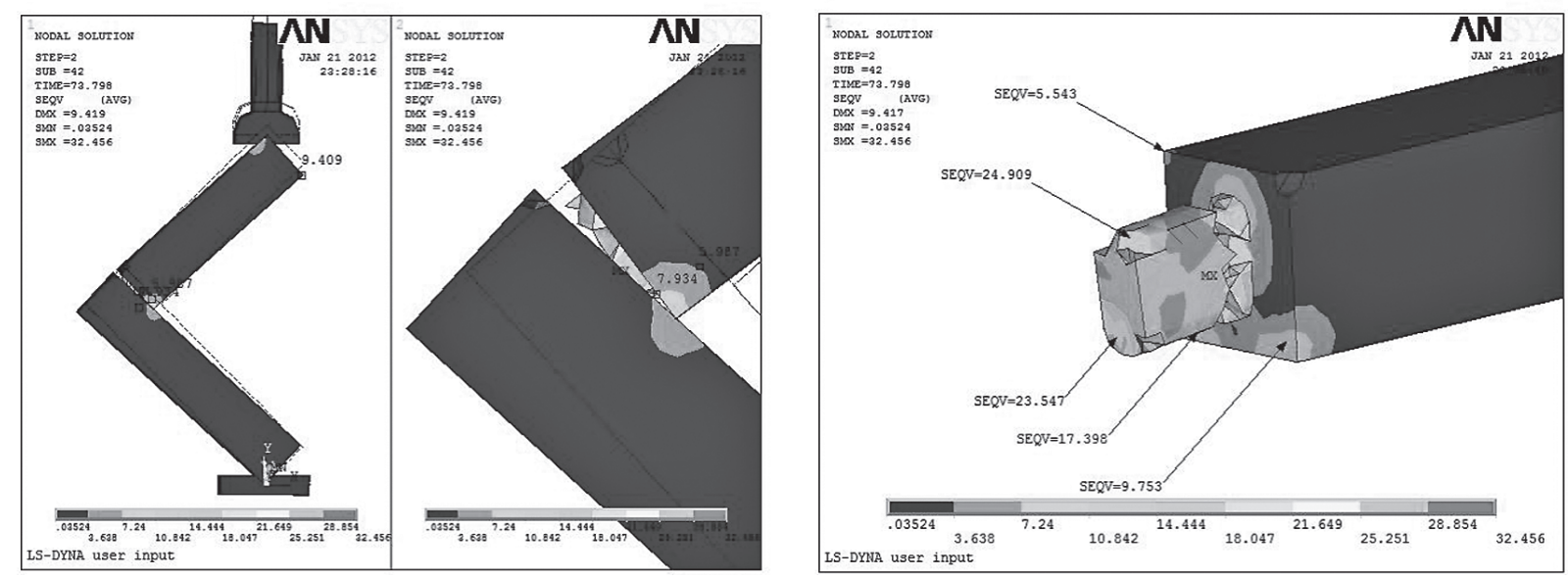

Figure 7 Diagonal compression strength stress and deformations in mortise-tenon joint of Scotch pine samples for diagonal compression tests

Slika 7. Dijagonalno tlačno naprezanje i deformacije u uzorku spoja čep - rupa izrađenome od drva bora pri ispitivanju dijagonalne tlačne čvrstoće 

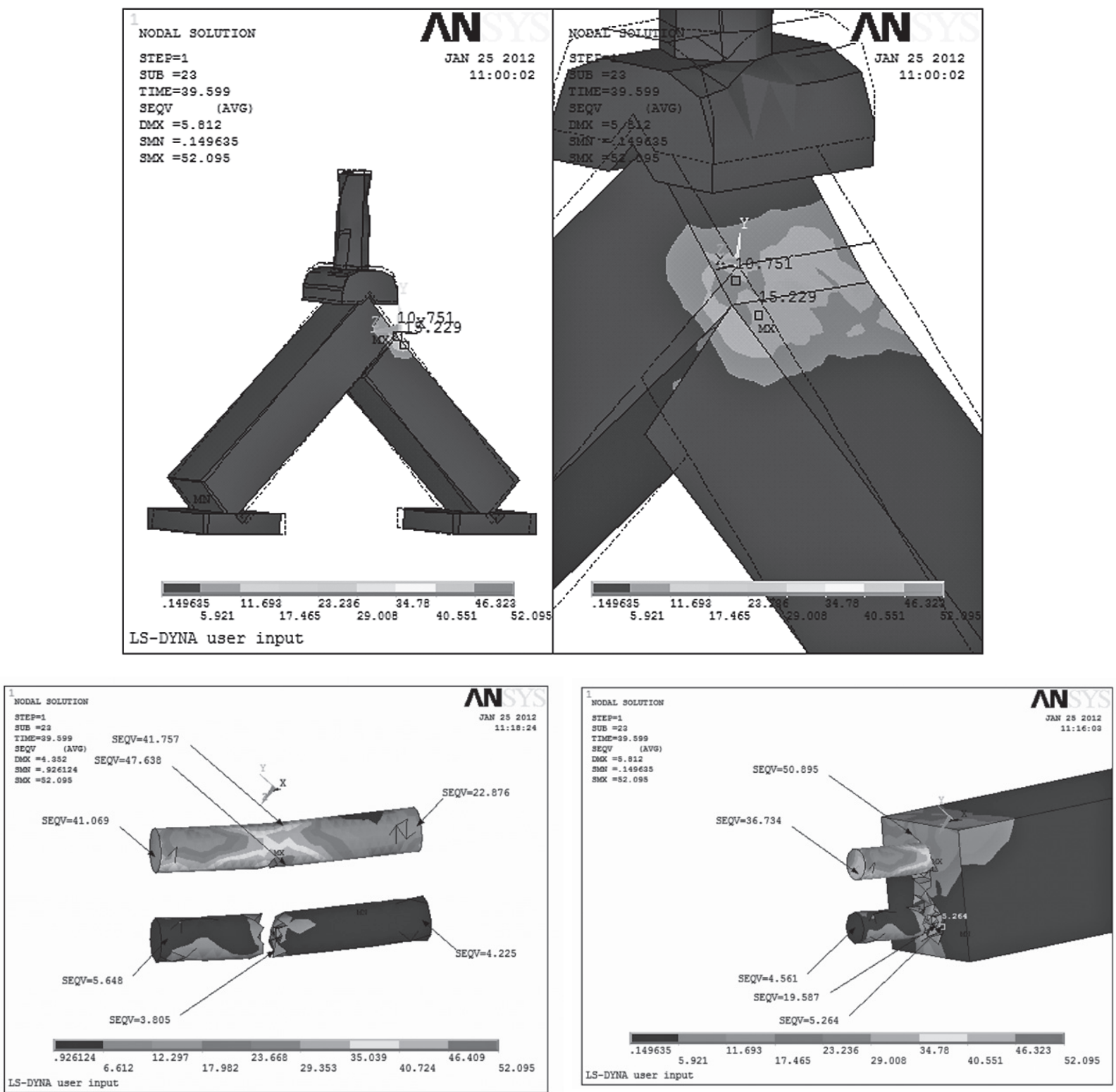

Figure 8 Diagonal tension strength stress and deformations in the dowel joint of beech samples for diagonal tension tests Slika 8. Dijagonalna vlačna naprezanja i deformacije spoja moždanikom, izrađenoga od drva bukve za ispitivanje dijagonalne vlačne čvrstoće
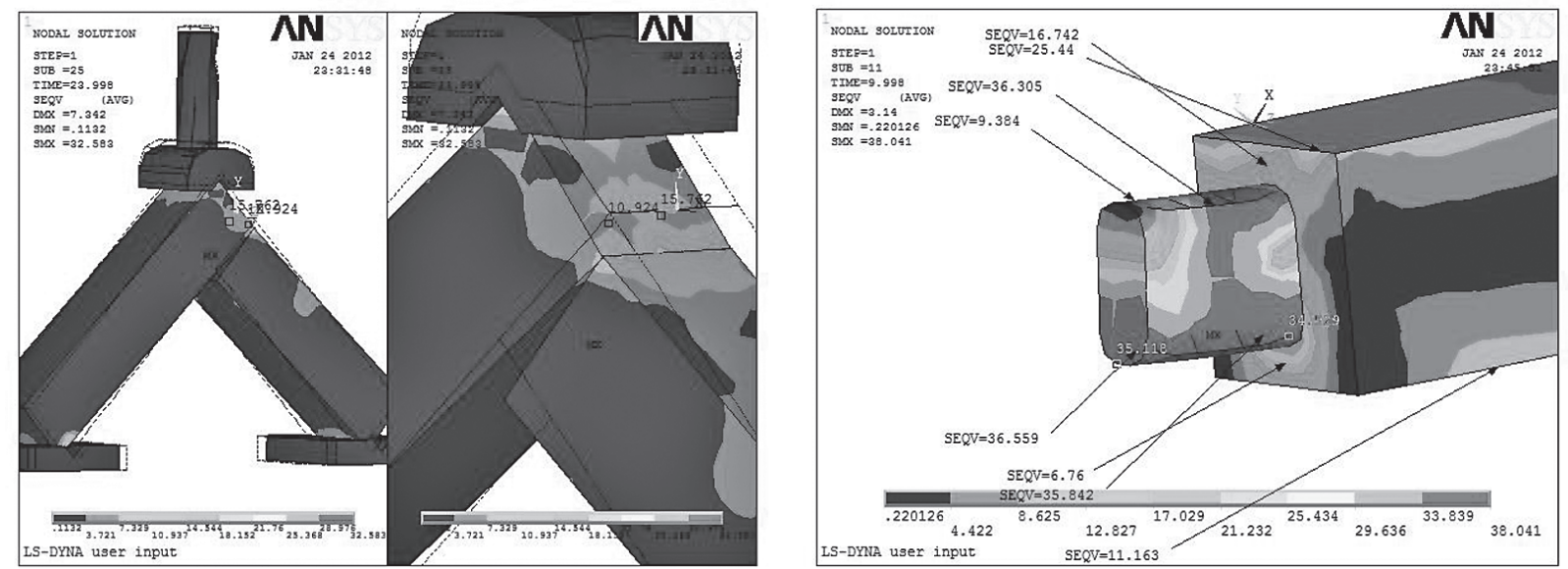

Figure 9 Diagonal tension strength stress and deformations in the mortise-tenon joint of Scotch pine samples for diagonal tension tests

Slika 9. Dijagonalna vlačna naprezanja i deformacije spoja rupa - čep izrađenoga od drva bora za ispitivanje dijagonalne vlačne čvrstoće 
In contrast to the diagonal compression test, in the diagonal tension tests of the L-type mortise-tenon corner joints, initial break occurred in the lower section of the tenon joint. Deformation and then break was also seen in the edge of element A mortise. The results of FEM computer modeling shown in Fig. 9 comply with the experiments.

\section{CONCLUSION \\ 4. ZAKLJUČAK}

In this study, the strength properties of "dowel and tenon corner joints", used in wood industries under various forces, were determined using "experimental methods" and "computer modeling ANSYS/LS-DYNA analysis program", and the results were compared. 1. The results of strength analysis by computer modeling as well as the results of the experimental methods revealed similar values (90-97 \%). Experimental data, that cannot be observed with naked eye or measurement techniques, can be obtained more sensitively and in more detailes with ANSYS/LS-DYNA computer modeling

2. "Strain analyses" were carried out to determine the effects of experiment samples on rigidity values in corner joint sections. By using strain gauges on the selected corner joints, strains were measured. In the experiments carried out with this technique, deformations at critical joint sections were measured and converted into stress values. In the light of these data, strength values of different sections can be determined and an idea can be viewed about what possible changes could be made to produce durable material designs.

3. Both experiments and computer modeling with ANSYS/LS-DYNA proved that deformations were mostly observed in the joint sections. These results imply that material designers should choose more appropriate construction models.

4. One of the biggest problems encountered during experiments is that at the end of the experiment materials are destructed, while computer modeling techniques, which can simulate real life conditions, offer non-destructive methods, thus reducing the expenses.

\section{Acknowledgments - Zahvala}

This research is a $\mathrm{PhD}$ thesis that is supported by the Faculty of Forestry in both Karabuk University and Bartin University.

\section{REFERENCES}

5. LITERATURA

1. Atar, M.; Ozcifci, A.; Altinok, M.; Celikel, U., 2009: Determination of diagonal compression and tension performances for case furniture corner joints constructed with wood biscuits. Materials\&Design, 30: 665-670. http://dx.doi.org/10.1016/j.matdes.2008.05.023.

2. BS EN204-2001: Classification of thermoplastic wood adhesives for non-structural applications. British Standards.

3. Cai, L.; Wang, F.; Tan, H., 1995: Study on the strength of moltinject corner joints of furniture. Holz Roh Werkst, 53(6): 385-388. http://dx.doi.org/10.1007/s001070050113.
4. Dalvand, M.; Ebrahimi, G.; Tajvidi, M.; Layeghi, M., 2014: Bending moment resistance of dowel corner joints in case-type furniture under diagonal compression load. Journal of Forestry Research, 25: 981-984. http://dx.doi.org/10.1007/s11676-014-0481-y.

5. DIN 68602-1979: Evaluation Of Adhesives For Joining Wood And Derived Timber Products, Strain Groups, Strength Of Bond. German Standards.

6. Eckelman, C. A.; Suddarth, S., 1969: Analysis and design of furniture frames. Wood Sci Technol, 3: 239-255. http://dx.doi.org/10.1007/BF00367215.

7. Guindos, P.; Guaita, M., 2013: A three-dimensional wood material model to simulate the behavior of wood with any type of knot at the macro-scale. Wood Sci Technol, 47: 585-599. http://dx.doi.org/10.1007/s00226-012-0517-4.

8. Gustafsson, S. I., 1995: Furniture design by use of finite element method. Holz Roh Werkst, 53: 257-260. http://dx.doi.org/10.1007/s001070050084.

9. Gustafsson, S. I., 1996: Finite Element Modeling versus reality for birch chairs. Holz Roh Werkst, 54: 355-359. http://dx.doi.org/10.1007/s001070050200.

10. Gustafsson, S. I., 1997: Optimizing ash wood chairs. Wood Sci Technol, 31: 291-301. http://dx.doi.org/10.1007/BF00702616.

11. Nicholls, T.; Crisan, R., 2002: Study of the stress-strain state in corner joints and box type furniture using Finite Element Analysis (FEA). Holz Roh Werkst, 60: 66-71. http://dx.doi.org/10.1007/s00107-001-0262-0.

12. Smardzewski, J., 1998: Numerical analysis of furniture constructions. Wood Sci Technol, 32: 273-286. http://dx.doi.org/10.1007/BF00702895.

13. Smardzewski, J., 2002: Strength of profile-adhesive joints. Wood Sci Technol, 32: 273-286. http://dx.doi.org/10.1007/s00226-001-0131-3.

14. Tankut, N.; Tankut, A. N.; Zor, M., 2014: Finite Element Analysis of Wood Materials. Drvna industrija, 65: 159171. http://dx.doi.org/10.5552/drind.2014.1254.

15. TS 2470-1976: Wood-Sampling Methods and General Requirements for Physical and Mechanical Tests. Turkish Standards.

16. TS 3891-1983: Adhesives-Polyvinyl acetate Emulsion. Turkish Standards.

17. TS 4539-1985: Wood Joints-Rules of Dowel Joint. Turkish Standards.

18. TS 4908-1986: Wood Joints- Rules of End to Side Grain Joints. Turkish Standards.

19. Yorur, H., 2012: Determination of Technological Properties in Simulation (ANSYS) Occasion for Wooden Corner Joints. Phd. Thesis. Bartin Univ., Bartin, Turkey.

20. İmirzi, H. Ö., 2008: Strength properties of case type furniture produced With different construction techniques and panel Thicknesses. Phd. Thesis, Gazi Univ., Ankara, Turkey.

21. Ertas, G. D., 2007: The effects of the structural characteristics on Industrial product design, Phd. Thesis, Istanbul Technical Univ., İstanbul, Turkey.

\section{Corresponding address:}

Assoc. Prof. BULENT KAYGIN, Ph.D.

Department of Forest Industry Engineering

Faculty of Forestry

Bartin University

74100, Bartin, TURKEY

e-mail: bkaygin@bartin.edu.tr 